\title{
Environmentálne vzdelávanie pre udržatel'ný rozvoj a ochranu biodiverzity v rámci vybraných študijných programov na Prírodovedeckej fakulte Univerzity Komenského v Bratislave (Slovenská verze)
}

\author{
Jana Ružičková, Marta Nevřelová, Blanka Lehotská \\ Envigogika 10 (2) - Reviewed Papers/ Recenzované články
}

Published/ Publikováno 20. 3. 2015

DOI : $10.14712 / 18023061.465$

\begin{abstract}
Abstrakt
Udržatel'ný rozvoj, biodiverzita a rozmanitost' kultúrnej krajiny by mala byt́ základnou súčastou vo vyučovaní nielen prírodovedných predmetov. Prírodovedecká fakulta UK v Bratislave vychováva odborníkov $v$ prírodných vedách a environmentalistike, $v$ magisterskom stupni najmä $v$ rámci študijných programov Environmentálne plánovanie a manažment a Ochrana a využívanie prírody a krajiny. Ciel'om analýz bolo hodnotenie povinných a povinne volitel'ných predmetov uvedených študijných programov z hladiska pokrytia tematických okruhov udržatel'ného rozvoja (UR). Študijné programy a štruktúra obsahového zamerania boli analyzované na základe 14 tematických okruhov. Výsledky ukázali, že 20 zo 41 predmetov pokrýva viac ako $50 \%$ tematických okruhov UR. Ostatné predmety, čo sú užšie zamerané, majú tiež svoj význam, nakolko podrobnejšie pokrývajú klúčové tematické okruhy napr. $v$ oblasti biodiverzity. Pripravenost' pre prax a kompetencie absolventov by mali byt' dostatočné, bolo by však vhodné podrobnejšie sa zamerat' na dané témy $v$ rámci predmetov aj z hl'adiska indikátorov UR.
\end{abstract}

\section{Kl'účové slová}

environmentalistika, udržatel'ný rozvoj, ochrana biodiverzity, výučba, kompetencie, prax

\begin{abstract}
Sustainable development, biodiversity and landscape diversity should be a key component in nature oriented curricula. The Faculty of Natural Sciences of Comenius University in Bratislava trains specialists in natural and environmental science in Master's degree, in particular in the context of the curricula "Environmental Planning and Management" and "Landscape Protection and Land Use". The aim of the analysis was to assess the compulsory and elective study subjects of the curricula in question in terms of coverage of themes of sustainable development (SD). The curricula structure and content were analysed on the basis of 14 themes. The results showed that 20 out of the 41 study subjects cover more than $50 \%$ of SD themes. The other subjects, more narrowly focused, are also of importance, because they cover key themes such as biodiversity in detail. Graduates' preparedness for practice and competencies should be sufficient, but it would be appropriate to also focus on the themes in the study subjects in terms of SD indicators.
\end{abstract}

\section{Keywords}

environmental science, sustainable development, biodiversity conservation, teaching, competences, practice 


\section{Úvod}

Environmentálna výchova a vzdelávanie sú významnými prvkami v stratégii starostlivosti o životné prostredie. Velký význam pri problémoch udržatel'ného rozvoja a ochrany biodiverzity zohráva šírenie environmentálnych poznatkov a informácií, základom by malo byt' environmentálne vzdelávanie, ktoré by malo viest' k získaniu skúseností v rozhodovaní a pri formovaní pravidiel správania sa človeka k prostrediu (Kminiak, 1997).

Environmentálne vzdelanie možno dnes nadobudnút na viacerých fakultách slovenských univerzít, a to formou magisterského alebo inžinierskeho štúdia, environmentálny pilier však tvorí len jednu čast' koncepcie udržatel'ného rozvoja. Ďalšími piliermi sú ekonomické, sociálne, či humánne princípy. V Deklarácii z J ohannesburgu (2002) bola sformulovaná téza „kolektívnej zodpovednosti za zlepšenie a posilnenie nezávislých a navzájom sa podporujúcich pilierov trvalo udržatel'ného rozvoja (Kates a kol., 2005).

Význam holistického prepojenia environmentálneho, ekonomického a sociálneho aspektu pre zadefinovanie výchovy k udržatel'nému rozvoju zdôraznil Hilbert (2007).

Vysokoškolské vzdelávanie by malo významne prispiet' $\mathrm{k}$ výchove $\mathrm{k}$ trvalo udržatel'nému rozvoju (VTUR) pri rozvíjaní patričných vedomostí a kompetencií (EHK, 2005). Podl'a Blažka (2010) sa francúzsky termín compétence pôvodne používal v kontexte odbornej prípravy a označoval schopnost' (spôsobilost') vykonat' určitú úlohu. Po preniknutí do sféry vzdelávania znamená tento termín určitú schopnost', či potenciál účinne jednat' v danom kontexte. Dnes už nemá význam samotný poznatok, ale jeho uplatnenie, využitie. Vytváranie kompetencií znamená potom umožnenie jednotlivcom, aby mobilizovali, uplatňovali a zapájali osvojené poznatky v zložitých, rozmanitých a nepredvídatelných situáciách. Pojem klúčové kompetencie je zvnútornený, vzájomne prepojený súbor nadobudnutých vedomostí, zručností, schopností, postojov a hodnotových orientácií, ktoré sú dôležité pre kvalitný rozvoj osobnosti jednotlivca, jeho aktívne zapojenie sa do spoločnosti, uplatnenie v zamestnaní a jeho celoživotné vzdelávanie.

Environmentálne vzdelávanie sa na Slovensku realizuje na všetkých stupňoch škôl vrátane vysokých škôl. Organickou a významnou súčastou environmentálnej výchovy sa stala problematika trvalo udržatelného rozvoja (TUR). Práve absolventi vysokých škôl sú potenciálnymi nositel'mi princípov trvalo udržatel'ného rozvoja $v$ rámci výkonu povolania pri ovplyvňovaní environmentálneho vedomia (Füry, Hlatká, 2013).

Tradícia environmentálneho vzdelávania $v$ slovenskom školstve je pomerne hlboko zakorenená, hoci v prvej etape svojho rozvoja sa úzko preplietala so špecifikami ekológie a ekologickej výchovy. Napokon, táto skutočnost́ viedla k postupnej infiltrácii oboch koncepčne rozdielnych pojmov, teda plne etablovanej ekologickej vedy a interdisciplinárne definovanej environmentalistiky. Nová generácia environmentálneho vzdelávania existenciu oboch koncepcií nepopiera, ale synteticky hladá ich spoločné témy do pohl'adu, v ktorom je environmentalistika založená na ekologických základoch a ekológia transponovaná do praktických environmentálnych problémov (Fedor, 2013).

Ciel'om príspevku bolo hodnotenie a porovnanie obsahu predmetov dvoch študijných programov magisterského štúdia na Prírodovedeckej fakulte Univerzity Komenského v Bratislave - Environmentálne plánovanie a manažment a Ochrana a využívanie prírody a krajiny - z hladiska pokrytia tematických okruhov udržatel'ného rozvoja (UR) v rámci výučby povinných a povinne volitel'ných predmetov. 


\section{Vzdelávanie k udržatel'nému rozvoju na slovenských vysokých školách}

Základy smerovania k trvalo udržatel'nému rozvoju a postupnú profiláciu odborníkov na úrovni česko-slovenskej spolupráce možno pozorovat' už v 90 . rokoch minulého storočia. Významným impulzom bolo založenie Spoločnosti pre trvalo udržatel'ný život (STUŽ), ktorá vznikla v septembri 1992 z iniciatívy Josefa Vavrouška - vtedajšieho ministra životného prostredia Českej a Slovenskej Federatívnej Republiky (ČSFR). V priebehu viac ako 20 rokov sa STUŽ na Slovensku zúčastňovala na riešení významných domácich projektov, vrátane Národnej stratégie trvalo udržatel'ného rozvoja SR (schválenej uznesením vlády SR č. 978/2001 a uznesením Národnej rady SR č. 1989/2002), na ktorú nadviazal akčný plán.

Akčný plán trvalo udržatel'ného rozvoja v SR na roky 2005-2010 definoval ako jeden zo svojich ciel'ov implementovanie základných princípov trvalo udržatel'ného rozvoja do učebných osnov na všetkých stupňoch škôl v SR a v systéme celoživotného vzdelávania. V tomto smere sa počítalo najmä so začlenením Stratégie vzdelávania k trvalo udržatel'nému rozvoju do vzdelávacieho procesu a s vypracovaním a schválením novej koncepcie environmentálnej výchovy a vzdelávania (Koločány, 2006). I novovaná Koncepcia environmentálnej výchovy a vzdelávania vo všetkých stupňoch škôl v Slovenskej republike a v systéme celoživotného vzdelávania bola schválená ministrom školstva SR a ministrom životného prostredia v júli 2006 a Akčný plán výchovy a vzdelávania k trvalo udržatel'nému rozvoju v SR na realizáciu koncepcie bol schválený v decembri 2006. Na nepriaznivý trend vývoja v tejto oblasti po skončení obdobia realizácie (2005-2010) uvedeného Akčného plánu a po prerušení činnosti Komisie pre výchovu a vzdelávanie k trvalo udržatel'nému rozvoju výchovy upozornil Huba (2013).

Podmienky pre implementáciu výchovy a vzdelávania k udržatel'nému rozvoju analyzovala Kozová (2007). Podl'a autorky je možné vel'mi dobre nadviazat' na koncepciu a všeobecne prijímanú realizáciu environmentálnej výchovy a vzdelávania, ktorá začala prenikat́ do výučby a vedeckého výskumu na vysokých školách už v 70. rokoch 20. storočia. $\mathrm{Na}$ základe podkladov o nových akreditovaných študijných programoch, ktoré sa začali realizovat' od šk. r. 2004/2005 môžeme uviest', že v súčasnosti sú na väčšine fakúlt vysokých škôl zaradené predmety, súvisiace s environmentálnou, sociálnou alebo ekonomickou dimenziou UR. Dôležitým medzníkom, významne ovplyvňujúcim vysoké školy, bol predvstupový proces a vstup Slovenska do Európskej únie v r. 2004. Významnou mierou sa rozšírila medzinárodná vedecká spolupráca a mobility učitel'ov a študentov, a to aj v rámci problematiky súvisiacej s udržatel'ným rozvojom (Kozová, 2008).

Hodnotené environmentálne zamerané študijné programy patria medzi študijné odbory zo skupiny prírodných vied, podskupiny ekologické a environmentálne vedy (www.portalvs.sk/sk/studijne-odbory). Podskupina ekologické a environmentálne vedy sa d'alej člení na 5 študijných odborov (tab. 1), v rámci ktorých zabezpečuje vzdelávanie v jednotlivých študijných programoch 10 vysokých škôl, resp. univerzít: 1. Prešovská univerzita (PU) v Prešove, Fakulta manažmentu (FM) a Fakulta humanitných a prírodných vied (FHPV); 2. Slovenská pol'nohospodárska univerzita (SPU) v Nitre, Fakulta európskych štúdií a regionálneho rozvoja (FEŠRR); 3. Stredoeurópska vysoká škola (SVŠ) v Skalici; 4. Technická univerzita (TU) v Košiciach, Hutnícka fakulta (HF), Stavebná fakulta (SVF) a Strojnícka fakulta (SjF); 5. Technická univerzita (TU) vo Zvolene, Fakulta ekológie a environmentalistiky (FEE); 6. Univerzita Komenského (UK) v Bratislave, Prírodovedecká fakulta (PriF); 7. Univerzita Konštantína Filozofa (UKF) v Nitre; 8. Univerzita Mateja Bela (UMB) v Banskej Bystrici, Fakulta prírodných vied (FPV); 9. Univerzita Pavla Jozefa Šafárika (UPJ Š) v Košiciach, Prírodovedecká fakulta (PF) a 10. Žilinská univerzita (ŽU) v Žiline. 
Tab. 1: Prehl'ad environmentálne zameraných študijných programov $v$ podskupine ekologické a environmentálne vedy $v$ rámci 5 študijných odborov na 10-tich slovenských vysokých školách, resp. univerzitách. Šedou farbou sú vyznačené nami hodnotené študijné programy.

\begin{tabular}{|c|c|c|}
\hline $\begin{array}{c}\text { Univerzita/ Vysoká škola, } \\
\text { fakulta }\end{array}$ & 1. stupeň & 2. stupeň \\
\hline \multicolumn{3}{|c|}{ 1. Študijný odbor: Ochrana a využívanie krajiny } \\
\hline SVŠ v Skalici & Životné prostredie & - \\
\hline TU vo Zvolene, FEE & Ekológia a využívanie krajiny & Ekológia a využívanie krajiny \\
\hline \multirow[b]{2}{*}{ UK v Bratislave, PriF } & \multirow[b]{2}{*}{ Environmentalistika } & Environmentálna geochémia \\
\hline & & $\begin{array}{l}\text { Ochrana a využívanie prírody } \\
\text { a krajiny }\end{array}$ \\
\hline UKF v Nitre & Environmentalistika & Environmentalistika \\
\hline ŽU v Žiline & Stráž prírody & - \\
\hline \multicolumn{3}{|c|}{ 2. Študijný odbor: Environmentálne inžinierstvo } \\
\hline TU v Košiciach, HF & $\begin{array}{l}\text { Spracovanie a recyklácia odpa- } \\
\text { dov }\end{array}$ & $\begin{array}{l}\text { Spracovanie a recyklácia od- } \\
\text { padov }\end{array}$ \\
\hline TU v Košiciach, SVF & $\begin{array}{l}\text { Environmentálne inžinierstvo } \\
\text { stavieb }\end{array}$ & $\begin{array}{l}\text { Stavby s environmentálnym } \\
\text { určením }\end{array}$ \\
\hline TU v Košiciach, SjF & $\begin{array}{l}\text { Technika ochrany životného } \\
\text { prostredia }\end{array}$ & $\begin{array}{l}\text { Technika ochrany životného } \\
\text { prostredia }\end{array}$ \\
\hline TU vo Zvolene, FEE & Environmentálne inžinierstvo & Environmentálne inžinierstvo \\
\hline \multicolumn{3}{|c|}{ 3. Študijný odbor: Environmentálny manažment } \\
\hline PU v Prešove, FM & Environmentálny manažment & - \\
\hline SPU v Nitre, FEŠRR & Environmentálne manažérstvo & Environmentálne manažérstvo \\
\hline SVŠ v Skalici & Environmentálne manažérstvo & Environmentálne manažérstvo \\
\hline TU vo Zvolene, FEE & Environmentálny manažment & Environmentálny manažment \\
\hline UK v Bratislave, PriF & Environmentalistika & $\begin{array}{l}\text { Environmentálne plánovanie a } \\
\text { manažment }\end{array}$ \\
\hline UMB v Banskej Bystrici, FPV & Environmentálne manažérstvo & Environmentálne manažérstvo \\
\hline \multicolumn{3}{|c|}{ 4. Študijný odbor: Všeobecná ekológia a ekológia jedinca a populácií } \\
\hline PU v Prešove, FHPV & Ekológia & Ekológia \\
\hline TU vo Zvolene, FEE & Ekológia a ochrana biodiverzity & $\begin{array}{l}\text { Ekológia a ochrana biodiver- } \\
\text { zity }\end{array}$ \\
\hline UK v Bratislave, PriF & - & Ekológia \\
\hline UPJŠ v Košiciach, PF & $\begin{array}{l}\text { Všeobecná ekológia a ekológia } \\
\text { jedinca a populácií }\end{array}$ & $\begin{array}{l}\text { Všeobecná ekológia a ekológia } \\
\text { jedinca a populácií }\end{array}$ \\
\hline \multicolumn{3}{|c|}{ 5. Študijný odbor: Synekológia } \\
\hline UMB v Banskej Bystrici, FPV & Systémová ekológia & Systémová ekológia \\
\hline
\end{tabular}

Vývoj environmentálneho vzdelávania na viacerých slovenských vysokých školách a univerzitách je prezentovaný v publikácii Stav a perspektívy environmentálneho vzdelávania 
(Fedor, Pavličková, eds., 2013). Environmentálne vzdelávanie na Prešovskej univerzite v Prešove približili Adamišin, Chovancová (2013). Perspektívy rozvoja štúdia environmentálneho inžinierstva na Slovenskej technickej univerzite v Bratislave prezentuje Čík (2013). Stav výučby ekológie a environmentalistiky na Slovenskej pol'nohospodárskej univerzite v Nitre analyzoval Eliáš (2013). Zhodnotenie výučby Environmentálnej výchovy a súvisiacich aktivít na Fakulte ekológie a environmentalistiky v období 1997-2013 spracovala Gallayová (2013).

Systematické vzdelávanie $v$ oblasti ochrany prírody a krajiny má na Prírodovedeckej fakulte UK v Bratislave dlhšiu tradíciu. V r. 1977 bol z iniciatívy významného zoológa a zakladatel'a ekosozológie (náuky o ochrane prírody na ekologickom základe) - Mikuláša J. Lisického, založený interdisciplinárny študijný odbor "Ochrana prírodného prostredia“, ktorý zabezpečovala vtedajšia Katedra systematickej a ekologickej zoológie (Kocian, 2013). V roku 1992 bola založená Environmentálna sekcia, ktorá vznikla združením štyroch pracovísk: Katedry geochémie, Katedry ekosozológie a fyziotaktiky ( $v$ súčasnosti Katedra environmentálnej ekológie), Katedry pedológie a Katedry krajinnej ekológie. Ciel'om študijného odboru Environmentalistika, ktorý bol vyprofilovaný v r. 1992, je vychovávat' odborníkov, schopných koordinovat' a riadit' environmentálne projekty, pracovat' $v$ interdisciplinárnych tímoch $v$ environmentálnom výskume, získat' odborné, organizačné a komunikačné predpoklady pre prácu $v$ štátnej správe $v$ oblasti životného prostredia, pôsobit na vedeckých pracoviskách a univerzitách, $v$ environmentálne zameraných firmách a environmentálnych mimovládnych organizáciách.

Prírodovedecká fakulta Univerzity Komenského v Bratislave pôsobí v oblasti prírodných vied a vychováva nielen odborníkov v biológii, chémii, geológii, geografii, ale aj v environmentalistike, kde sa problematika udržatel'ného rozvoja a ochrany biodiverzity uplatňuje najmä v magisterských študijných programoch Environmentálne plánovanie a manažment a Ochrana a využívanie prírody a krajiny, ktoré nadväzujú na bakalársky študijný program Environmentalistika. Oba uvedené študijné programy v rámci magisterského stupňa štúdia sú otvorené od r. 2005/2006. Nosnými témami sú: udržatelný rozvoj, environmentálne plánovanie, posudzovanie vplyvov na životné prostredie, monitoring životného prostredia, manažment krajiny, krajinné plánovanie, systémy riadenia, a d’alšie. Študijné programy vychádzajú $z$ dlhšej tradície environmentálneho vzdelávania a sú v súlade s prioritami Akčného plánu trvalo udržatel'ného rozvoja v SR na roky 2005-2010, ktorý obsahoval 14 prioritných oblastí. V oblasti výchovy a vzdelávania to boli oblasti: 9. Príprava l'udských zdrojov na implementáciu TUR do rozhodovania štátnych orgánov SR; 10. Ochrana a racionálne využívanie prírody a krajiny; 12 . Implementovanie základných princípov trvalo udržatel'ného rozvoja do učebných osnov na všetkých stupňoch škôl v SR a v systéme celoživotného vzdelávania.

\section{Metodický postup}

V rámci analýz študijných programov magisterského štúdia Environmentálne plánovanie a manažment a Ochrana a využívanie prírody a krajiny sme hodnotili potenciálnu pripravenost́ a kompetencie absolventov vyššie uvedených študijných programov platných v školskom roku 2014/2015 (Rybárová, ed., 2014b, www.fns.uniba.sk).

Metodický postup analýzy uvedených študijných programov bol zameraný na vyhodnotenie obsahu prednášok, seminárov a cvičení povinných a povinne volitel'ných predmetov. Pozornost' bola sústredená na prezenciu, resp. absenciu tematických okruhov udržatel'ného rozvoja (UR) v jednotlivých predmetoch v rámci výučby. Následne bolo vyhodnotené: 1) aké 
percento predmetov obsahuje daný tematický okruh a 2) kol'ko tematických okruhov pokrývajú jednotlivé predmety (obr. 1,2). Študijné programy a štruktúra obsahového zamerania boli porovnávané na základe tematických okruhov Komisie OSN (tab. 2).

Súbor indikátorov udržatel'nosti Komisie OSN pre trvalo udržatel'ný rozvoj obsahuje 50 základných indikátorov. Súbor indikátorov udržatel'nosti, spracovaný na pôde Organizácie spojených národov obsahuje 50 základných indikátorov, ktoré spíňajú tri kritériá: pokrývajú tematické okruhy, ktoré sa týkajú väčšiny štátov, poskytujú zásadnú informáciu, ktorú neposkytuje žiadny iný indikátor, môžu byt́ vyhodnotené vo väčšine krajín na základe dostupných, alebo reálne získatel'ných údajov. Rozdelenie indikátorov podla štyroch základných pilierov (sociálny, ekonomický, environmentálny a inštitucionálny) nie je explicitné, nakolko rešpektuje význam vzájomnej integrácie uvedených pilierov, čo v praxi znamená, že jeden indikátor môže byt́ aplikovaný aj pri viacerých tematických okruhoch. Tematických okruhov je 14 a sú nasledovné: 1 . chudoba, 2. vládna moc, 3. zdravie, 4. vzdelanie, 5. demografia, 6. prírodné riziká, 7. atmosféra, 8. krajina, 9. oceány, moria a pobrežia, 10. sladká voda, 11. biodiverzita, 12. ekonomický rozvoj, 13. globálne ekonomické partnerstvo, 14. modely konzumu a produkcie (United Nations, 2007). Uvedené tematické okruhy sú komplexne chápané a korešpondujú s prioritnými tematickými okruhmi Európskej únie (Eurostat, 2011). Porovnanie tematických okruhov po úroveň podtém je uvedené $v$ tabulke 2 . $Z$ hladiska porovnania podtém sú tematické okruhy $v$ zmysle OSN a podla Európskej únie chápané v prevažnej miere vel'mi podobne, určité rozdiely sú v tematických okruhoch 2. vládna moc a 3. zdravie. $\vee$ súbore Európskej únie nie je priamo uvedená téma 6. prírodné riziká.

Bakalársky stupeň vzdelávania v odbore Environmentalistika je pre oba hodnotené magisterské študijné programy spoločný, preto uvádzame stručný prehl'ad predmetov, ktoré tvoria obsah štúdia, a ktoré najviac korešpondujú s tematikou udržatel'ného rozvoja. 
Tab. 2: Porovnanie prioritných tematických okruhov a podtém udržatel'ného rozvoja v svetovom a európskom kontexte.

\begin{tabular}{|c|c|c|}
\hline \multirow{2}{*}{ Č. } & \multicolumn{2}{|c|}{ TEMATI CKÉ OKRUHY A PODTÉMY UR } \\
\hline & OSN (United Nations, 2007) & Európska únia (Eurostat, 2011) \\
\hline 1. & $\begin{array}{l}\text { Chudoba } \\
\text { - príjmová chudoba } \\
\text { - nerovnost' príjmov } \\
\text { - hygiena } \\
\text { - pitná voda } \\
\text { - prístup k energiám } \\
\text { - životné podmienky }\end{array}$ & $\begin{array}{l}\text { Chudoba a sociálna inklúzia } \\
\text { - peňažná chudoba a životné podmienky } \\
\text { - prístup k trhu práce }\end{array}$ \\
\hline 2. & $\begin{array}{l}\text { Vládna moc } \\
\text { - korupcia } \\
\text { - kriminalita }\end{array}$ & $\begin{array}{l}\text { Dobre spravované verejné veci } \\
\text { - súdržnost' a efektívnost' politiky } \\
\text { - otvorenost' a participácia } \\
\text { - ekonomické nástroje }\end{array}$ \\
\hline 3. & $\begin{array}{l}\text { Zdravie } \\
\text { - úmrtnost' } \\
\text { - dostupnost́ zdravotnej starostlivosti } \\
\text { - úroveň výživy } \\
\text { - zdravotný stav a riziká }\end{array}$ & $\begin{array}{l}\text { Verejné zdravie } \\
\text { - zdravie a nerovnosti v oblasti zdravia } \\
\text { - determinanty zdravia }\end{array}$ \\
\hline 4. & $\begin{array}{l}\text { Vzdelanie } \\
\text { - úroveň vzdelania } \\
\text { - gramotnost' }\end{array}$ & $\begin{array}{l}\text { Chudoba a sociálna inklúzia } \\
\text { - vzdelanie }\end{array}$ \\
\hline 5. & $\begin{array}{l}\text { Demografia } \\
\text { - zmeny v populácii }\end{array}$ & $\begin{array}{l}\text { Demografické zmeny } \\
\text { - demografia } \\
\text { - adekvátnost' príjmov v starobe } \\
\text { - udržatel'nost' verejných financií }\end{array}$ \\
\hline 6. & $\begin{array}{l}\text { Prírodné riziká } \\
\text { - zranitel'nost' voči prírodným rizikám } \\
\text { - pripravenost' a reakcia na katastrofy }\end{array}$ & \\
\hline 7. & $\begin{array}{l}\text { Atmosféra } \\
\text { - klimatické zmeny } \\
\text { - narušenie ozónovej vrstvy } \\
\text { - kvalita ovzdušia }\end{array}$ & $\begin{array}{l}\text { Klimatické zmeny a energia } \\
\text { - klimatické zmeny } \\
\text { - energia }\end{array}$ \\
\hline 8. & $\begin{array}{l}\text { Krajina } \\
\text { - stav a využitie krajiny } \\
\text { - dezertifikácia } \\
\text { - pol'nohospodárstvo } \\
\text { - lesníctvo }\end{array}$ & $\begin{array}{l}\text { Prírodné zdroje } \\
\text { - využitie krajiny }\end{array}$ \\
\hline 9. & $\begin{array}{l}\text { Oceány, moria a pobrežia } \\
\text { - pobrežná zóna } \\
\text { - rybárstvo } \\
\text { - morské prostredie }\end{array}$ & $\begin{array}{l}\text { Prírodné zdroje } \\
\text { - morské ekosystémy }\end{array}$ \\
\hline 10. & $\begin{array}{l}\text { Sladká voda } \\
\text { - množstvo vody } \\
\text { - kvalita vody }\end{array}$ & $\begin{array}{l}\text { Prírodné zdroje } \\
\text { - sladkovodné zdroje }\end{array}$ \\
\hline 11. & $\begin{array}{l}\text { Biodiverzita } \\
\text { - ekosystémy } \\
\text { - druhy }\end{array}$ & $\begin{array}{l}\text { Prírodné zdroje } \\
\text { - biodiverzita }\end{array}$ \\
\hline 12. & $\begin{array}{l}\text { Ekonomický rozvoj } \\
\text { - makroekonomické ukazovatele } \\
\text { - udržatel'né verejné financie } \\
\text { - zamestnanost' } \\
\text { - informačné a komunikačné technológie } \\
\text { - výskum a vývoj } \\
\text { - turizmus }\end{array}$ & $\begin{array}{l}\text { Sociálno-ekonomický rozvoj } \\
\text { - ekonomický rozvoj } \\
\text { - inovácie, konkurencieschopnost', ekologická efektívnost' } \\
\text { - zamestnanost' }\end{array}$ \\
\hline 13. & $\begin{array}{l}\text { Globálne ekonomické partnerstvo } \\
\text { - obchod } \\
\text { - externé zdroje financovania }\end{array}$ & $\begin{array}{l}\text { Globálne partnerstvo } \\
\text { - oficiálna rozvojová pomoc } \\
\text { - globalizácia obchodu } \\
\text { - financovanie udržatel'ného rozvoja } \\
\text { - riadenie globálnych zdrojov }\end{array}$ \\
\hline \multirow[t]{2}{*}{14.} & \multirow{2}{*}{$\begin{array}{l}\text { Modely konzumu a produkcie } \\
\text { - spotreba materiálu } \\
\text { - energie } \\
\text { - produkcia odpadov a manažment } \\
\text { - doprava }\end{array}$} & $\begin{array}{l}\text { Udržatel'ná spotreba a výroba } \\
\text { - využívanie zdrojov a odpady } \\
\text { - štruktúra spotreby } \\
\text { - štruktúra výroby }\end{array}$ \\
\hline & & $\begin{array}{l}\text { Udržatel'ná doprava } \\
\text { - doprava a mobilita } \\
\text { - vplyvy dopravy }\end{array}$ \\
\hline
\end{tabular}




\section{Environmentálne vzdelávanie - bakalársky stupeň}

Ciel’om bakalárskeho stupňa vzdelávania v rámci študijného programu Environmentalistika na PriF UK v Bratislave je získat' široký prírodovedný základ základných disciplín botaniky, zoológie, pedológie, geológie, chémie, geografie, na ktoré potom nadväzujú syntetické predmety, kde poslucháči získavajú poznatky z ekológie, ekosozológie (náuky o ochrane prírody na ekologickom základe), krajinnej ekológie a z environmentalistiky. V rámci interdisciplinárneho charakteru študijného programu Environmentalistika poslucháči majú možnost' získat' široké spektrum vedomostí, informácií a zručností. Vstupom do štúdia environmentalistiky je predmet Základy ekosozológie, v rámci ktorého sa objasňujú filozofické aspekty vzt́ahu človeka a prírody, získavajú informácie o historickom prehlade aktivít vo vzt́ahu človeka k životnému prostrediu (Nevřelová, 2013). Nadväzujúci predmet Územná ochrana je orientovaný na uplatnenie kategórií územnej ochrany a medzinárodnej spolupráce v podmienkach Slovenska a v európskom kontexte.

Z hl'adiska udržatel'ného rozvoja sú v študijných plánoch bakalárskeho stupňa štúdia (Rybárová, ed., 2014a) obsiahnuté nasledovné tematické okruhy (ktoré pokrývajú vybrané predmety): 6. prírodné riziká (Chémia a životné prostredie, Ekotoxikológia pre environmentalistov), 7. atmosféra (Meteorológia), 8. krajina (Krajinná ekológia, Ochrana a využívanie krajiny), 9. oceány, moria a pobrežia (Regionálna biogeografia, Ochrana a využívanie prírodných zdrojov), 10. sladká voda (Hydrológia a hydrogeológia), 12. Ekonomický rozvoj (Obec a životné prostredie, Tvorba a manažment priestorov rekreácie). Ťažisko však spočíva na téme č. 11. biodiverzita, ktorú pokrývajú viaceré predmety (Botanika - nižšie a vyššie rastliny, Zoológia bezstavovcov a stavovcov, Geobotanika, Biotopy 1, Biotopy 2, Zoosozologické praktikum, Fytosozologické praktikum a d'alšie). Medzi syntetické predmety patria napr. Úvod do biologických remediácií a Environmentálne plánovanie a manažment. Na rozvoj komunikačných schopností študentov je zameraný predmet Komunikácia v environmentalistike.

V bakalárskom stupni štúdia v rámci študijného programu Environmentalistika sú integrálnou súčast́ou environmentálneho vzdelávania terénne práce a exkurzie. Terénne práce z ekosozológie a krajinnej ekológie sú zamerané na ekosozologické aspekty (stav ochrany prírody) a manažment navštívených lokalít. V nadväznosti na teoretické poznatky študenti absolvujú aj terénne práce z botaniky, zo zoológie a z pedológie. Terénne práce z botaniky umožňujú bližšie oboznámenie sa s rastlinstvom rôznych typov biotopov (napr. mokré lúky v okolí riek Morava a Dunaj, xerotermné spoločenstvá Devínskej Kobyly, lesné spoločenstvá Malých Karpát). Terénne práce zo zoológie sú zamerané na poznávanie živočíchov priamo v teréne, oboznámenie študentov so základnými metódami získavania faunistických dát, s vyhladávaním, určovaním a interpretáciou pobytových znakov živočíchov. Terénne práce z pedológie sú zamerané na poznávanie a určovanie celej škály pôdnych typov na vybraných lokalitách $v$ rámci celého Slovenska. $\vee$ rámci praktického predmetu Ochrana bioty $v$ praxi sa študenti oboznamujú s možnost́ami a rôznymi formami zabezpečenia ochrany vybraných skupín bioty, ktoré sa realizujú v SR a v okolitých štátoch. Súčast́ou výučby je zapojenie sa do konkrétnych akcií zameraných na zabezpečenie ochrany vybraných skupín živočíchov (napr. obojživelníky, plazy, vtáky, cicavce), príp. rastlín (napr. vstavačovité - čel'ad’ Orchideaceae) s ciel'om získat́ nové poznatky a praktické skúsenosti.

\section{Environmentálne vzdelávanie - magisterský stupeň, analýza podl’a tematických okruhov udržatel'ného rozvoja}

V magisterskom stupni štúdia na PriF UK v Bratislave (Rybárová, ed., 2014b) je environmentálne vzdelávanie pre udržatel'ný rozvoj a ochranu biodiverzity uskutočňované najmä 
v dvoch študijných programoch: 1. Environmentálne plánovanie a manažment a 2. Ochrana a využívanie prírody a krajiny.

Do študijného programu Environmentálne plánovanie a manažment boli pri jeho koncipovaní cielene zaradené predmety, zamerané na problematiku udržatel'ného rozvoja, pričom jeho nosnými témami sú: udržatel'ný rozvoj, environmentálne plánovanie, posudzovanie vplyvov na životné prostredie, monitoring životného prostredia, krajinné plánovanie a d'alšie (Pauditšová, 2012). Z hladiska kompetencií by mal absolvent získat' komplexné a interdisciplinárne znalosti $v$ oblasti ochrany životného prostredia, environmentálnej politiky, manažmentu krajiny a udržatel'ného rozvoja a vediet' spolupracovat' v tíme odborníkov rôznych profesií na vysokej odbornej a technickej úrovni.

Študijný program Ochrana a využívanie prírody a krajiny je viac orientovaný na problematiku ochrany prírody, biodiverzity, a environmentálnej ekológie, čomu zodpovedá štruktúra a obsahové zameranie povinných a povinne volitelných predmetov uvedených študijných programov, nosnými témami študijného programu sú: ochrana prírody a krajiny, ochrana biodiverzity, environmentálna ekológia a environmentálne riziká. Absolvent by mal byt́ kompetentný riešit problémy ohrozenia kvality jednotlivých zložiek životného prostredia, syntetizovat' získané poznatky, vyhodnocovat' ich a navrhovat' konkrétne opatrenia na riešenie problémov ochrany prírody a krajiny na rôznych úrovniach.

$\checkmark$ rámci dvoch uvedených magisterských študijných programov sme analyzovali obsahovú náplň 41 predmetov, z toho 18 povinných (1 spoločný) a 23 povinne volitel'ných predmetov ( 1 spoločný) (obr. 1, 2).

Výsledky analýz ukázali, že 20 predmetov z celkového počtu 41 pokrýva 50-100 \% (7-14) tematických okruhov UR, z toho 12 predmetov je povinných a 8 povinne volitelných. J ednotlivé predmety a tematické okruhy UR sú prezentované na obr. 1 . $V$ študijnom programe: 1. Environmentálne plánovanie a manažment (EPM) ide o 7 povinných a 4 povinne volitel'né predmety. $\vee$ študijnom programe 2 . Ochrana a využívanie prírody a krajiny (OVPK) pokrývajú viac ako $50 \%$ tematických okruhov UR 4 povinné a 3 povinne volitel'né predmety. Dva predmety (1 povinný a 1 povinne volitel'ný) sú spoločné pre oba študijné programy. 


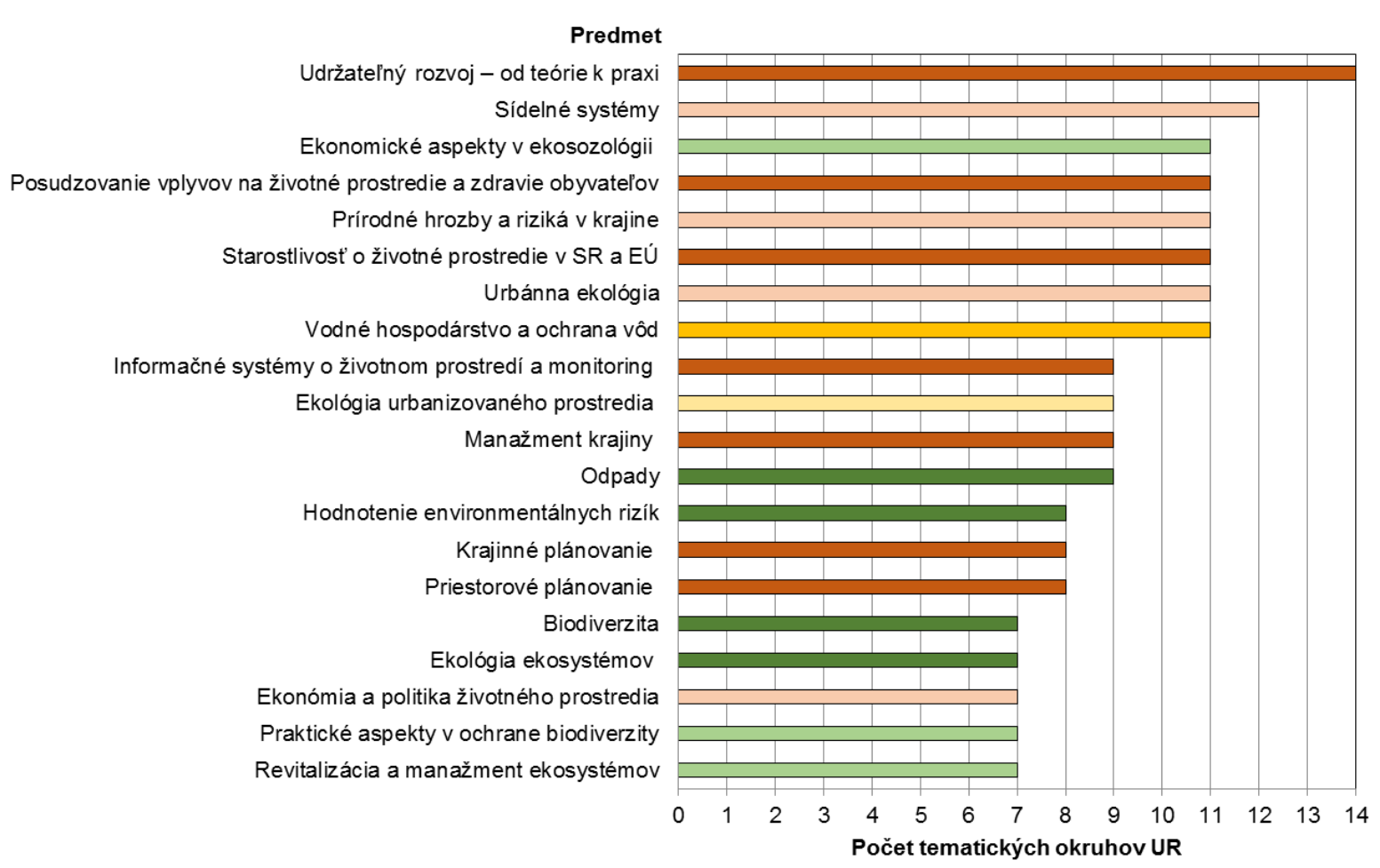

Obr. 1: Zastúpenie jednotlivých tematických okruhov UR v predmetoch študijných programov Environmentálne plánovanie a manažment (červená farba: tmavá - povinné predmety, svetlá - povinne volitel'né predmety) a Ochrana a využívanie prírody a krajiny (zelená farba: tmavá - povinné predmety, svetlá - povinne volitel'né predmety) v akademickom roku 2014/2015. Žltou sú vyznačené predmety, vyučované v oboch študijných programoch. (predmety spracované podla Rybárová, ed., 2014b)

Všetky tematické okruhy UR logicky pokrýva predmet Udržatel'ný rozvoj - od teórie $\mathrm{k}$ praxi. Predmet poskytuje študentom študijného programu Environmentálne plánovanie a manažment aktuálny prehlad o problematike udržatel'ného rozvoja, študenti sa naučia správne identifikovat' strategické priority a formulovat' alternatívne rozvojové scenáre územného rozvoja na miestnej a regionálnej úrovni. $V$ rámci študijného procesu študenti pochopia globálne princípy, kritériá a indikátory dôležité pre zabezpečenie udržatel'ného rozvoja na globálnej úrovni.

Na obr. 1 uvádzame predmety pokrývajúce 7 a viac tematických okruhov UR. Ostatné predmety sú v rámci študijných programov EPM (označené ${ }^{1}$ ) a OVPK (označené2) užšie zamerané (pokrývajú 6 a menej tematických okruhov), napr.: 6. prírodné riziká (Prírodné hrozby a riziká v krajine ${ }^{1}$, Hodnotenie environmentálnych rizík $^{2}$ ), 8. krajina (Alternatívne formy hospodárenia na pôde ${ }^{1}$, Aplikovaná krajinná ekológia ${ }^{1}$, Ekologické siete $v$ pol'nohospodárskej a lesnej krajine ${ }^{2}$ ), 10. sladká voda (Fluviálne geosystémy a ich manažment ${ }^{1}$ ), 11. biodiverzita (Ekosystémy Slovenska²), 12. Ekonomický rozvoj (Systémy riadenia a personálny manažment ${ }^{1}$ ) a 14 . Modely konzumu a produkcie (Manažment odpadového hospodárstva v procese plánovania ${ }^{1}$, Environmentálne biotechnológie²). Pre pedagógov je tu vysoký potenciál tieto tematické okruhy systematicky rozvíjat' a prezentovat'.

Pre oba študijné programy je prioritnou téma krajiny. Stavom, vývojom a spôsobmi využívania krajiny, sa zaoberá cca 90 \% predmetov oboch študijných programov. Nosnými sú povinné predmety Krajinné plánovanie ${ }^{1}$, Priestorové plánovanie ${ }^{1}$ a Manažment krajiny ${ }^{1} a$ 
možno sem zaradit' aj Posudzovanie vplyvov na životné prostredie a zdravie obyvatelov ${ }^{1}$ (obr. 2).

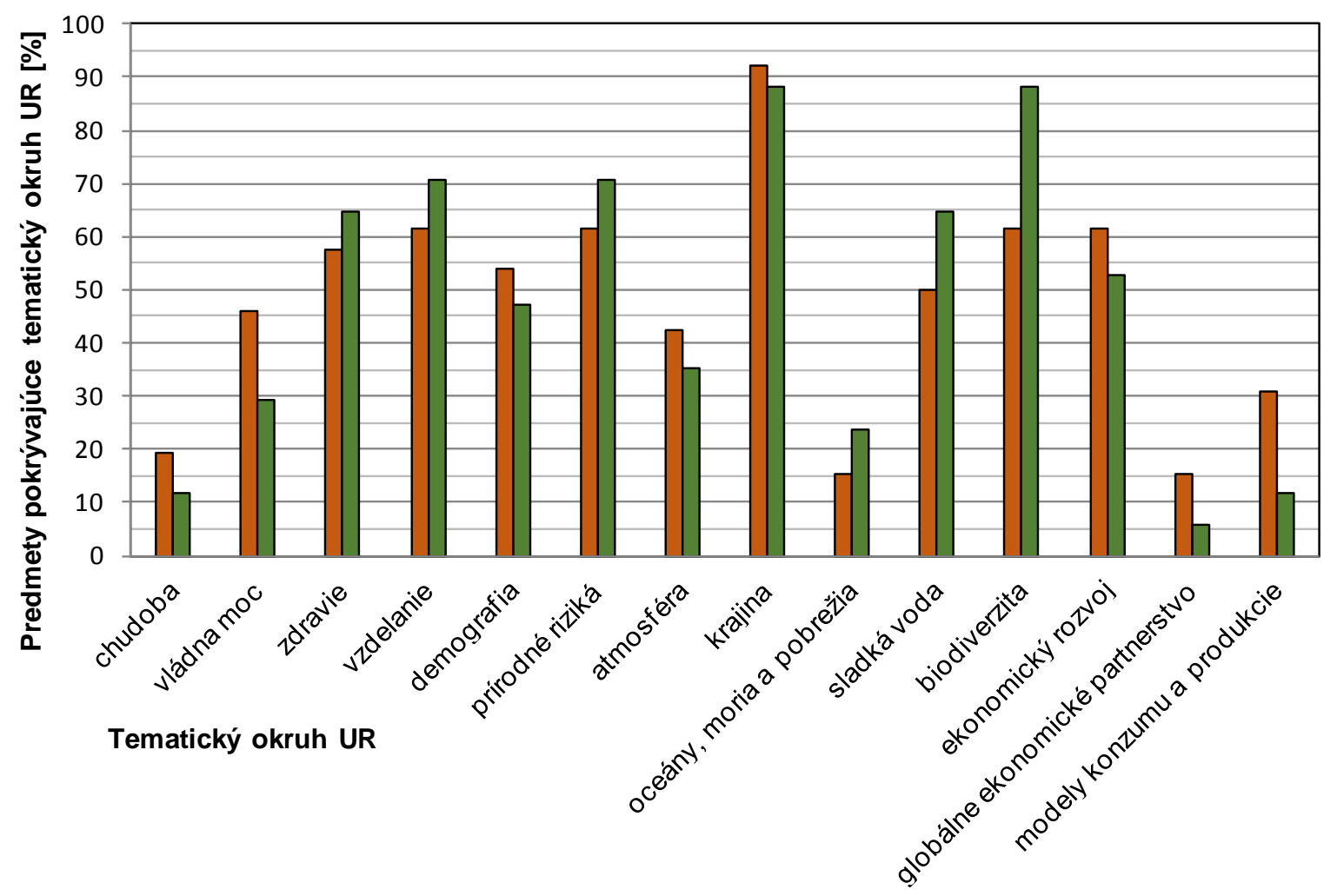

\section{Študijný program}

口Environmentálne plánovanie a manažment aOchrana a využívanie prírody a krajiny

Obr. 2: Percentuálne zastúpenie tematických okruhov v jednotlivých predmetoch študijných programov Environmentálne plánovanie a manažment a Ochrana prírody a krajiny $v$ akademickom roku 2014/2015 (predmety spracované podla Rybárová, ed., 2014b)

Predmet Krajinné plánovanie ${ }^{1}$ je zameraný na stanovenie ekologicky optimálneho využitia krajiny, nové trendy v krajinnej ekológii a metodické postupy súvisiacich plánovacích postupov. Predmet Priestorové plánovanie ${ }^{1}$ sa zaoberá problematikou územného rozvoja od lokálnej úrovne (územný plán obce) cez národnú úroveň (Koncepcia územného rozvoja Slovenska) až po medzinárodné súvislosti a očakávané trendy v kontexte Európskej integrácie. Predmet Manažment krajiny ${ }^{1}$ je zameraný na dynamiku vývoja vztáahu človeka a prírody, hodnotenie priaznivého stavu vybraných biotopov, rastlinných a živočišnych taxónov, ako aj zásady a princípy uplatnenia zásad udržatel'ného rozvoja a krajinnoekologických koncepcií $\checkmark$ manažmente krajiny. $\mathrm{V}$ predmete Posudzovanie vplyvov na životné prostredie a zdravie obyvatelo ${ }^{1}$ sú prezentované základné metodické postupy posudzovania a účel zákona NR SR č. 24/2006 Z. z. o posudzovaní vplyvov na životné prostredie a o zmene a doplnení niektorých zákonov $v$ znení neskorších predpisov.

$Z$ povinne volitel'ných predmetov téma krajiny dominuje napr. $v$ predmetoch: Ekologické siete $v$ pol'nohospodárskej a lesnej krajine1,2, Sídelné systémy1 a Urbánna ekológia1. 
Predmet Ekologické siete $v$ pol'nohospodárskej a lesnej krajine1,2 je zameraný na koncepcie ekologických sietí v Európskych krajinách aj vo svete, ktoré obsahujú v sebe preventívnu úlohu zachovat́ funkčnost' a variabilitu ekosystémov aj pre budúce generácie v súlade $s$ ekologickým princípom udržatel'ného rozvoja. Predmet Sídelné systémy1 sa zaoberá problematikou osídlenia, sídelných prvkov, organizáciou, plánovaním a reguláciou vývoja sídelných systémov u nás, ako aj novými trendami urbanizácie sveta a globalizáciou.

V študijnom programe Ochrana a využívanie prírody a krajiny najviac rezonuje okrem témy krajiny aj problematika ochrany biodiverzity. Intenzívna pozornost' sa jej venuje najmä v povinných predmetoch ako sú Biodiverzita ${ }^{2}$ a Ekológia ekosystémov ${ }^{2}$. Predmet Biodiverzita ${ }^{2}$ sa zaoberá stavom biologickej diverzity a jej zmenami a globálnymi trendmi vývoja v priestorovom i časovom meradle $v$ zmysle prirodzených aj antropogénne podmienených fenoménov. $V$ predmete Ekológia ekosystémov² sú prezentované klúčové poznatky o definovaní ekosystému s ciel'om poukázat' na jeho signifikantné postavenie v prírode. Venuje sa základným kvantitatívnym, štrukturálnym a vztahovým charakteristikám spoločenstiev.

Z povinne volitel'ných predmetov dopíňajú spektrum predmetov $\mathrm{k}$ tme biodiverzity napr.: Ekológia urbanizovaného prostredia ${ }^{1,2}$, Ekosystémy Slovenska ${ }^{2}$, Praktické aspekty $v$ ochrane biodiverzity ${ }^{2}$ a Revitalizácia a manažment ekosystémov ${ }^{2}$. Ekológia urbanizovaného prostredia $^{1,2}$ oboznamuje študentov $\mathrm{s}$ obsahom a predmetom ekologicky orientovaného výskumu $v$ urbanizovanom prostredí. Okrem charakteristiky základných ekologických činitel'ov sa venuje problematike pôvodu a rozšírenia vegetácie a fauny a ich výskumu a tiež funkciám a mapovaniu biotopov a ich postaveniu v urbanizovanom prostredí. Ekosystémy Slovenska² poznatkovou bázou nadväzujú na predmety botanika, zoológia, pedológia a ekológia. Na základe rozšírenia rôznych geoekologických jednotiek na území Slovenska analyzujú zastúpené ekosystémy, ich stanovištné nároky, vertikálnu a horizontálnu štruktúru, floristické a faunistické zloženie, syntaxonomické jednotky systému, biotické vztahy, ich rozšírenie na území Slovenska, obhospodarovanie a udržatel'né využívanie. Predmet Praktické aspekty $v$ ochrane biodiverzity ${ }^{2}$ približuje problematiku ochrany biodiverzity z hladiska jej praktického významu pre človeka. Ďalším aspektom je uplatnenie poznatkov ochrany biodiverzity $v$ ekosozologickej praxi. Prednášky, semináre a terénne cvičenia sú venované aj ochrane prírodného aj kultúrneho genofondu in situ, ex situ a in farm. Revitalizácia a manažment ekosystémov ${ }^{2}$ je predmet, zameraný na aktuálnu problematiku revitalizácie, obnovy, renaturácie a zakladania prírodných systémov, ktoré boli silne poškodené alebo úplne zlikvidované. Séria prednášok je vedená formou analýzy vybraných problémov vo vzt́ahu k vodným, mokrad'ovým, lesným i xerotermným ekosystémom.

Oba študijné programy ponúkajú predmety, ktoré sú spojené s témami, ktoré sú pre Prírodovedeckú fakultu UK interdisciplinárne a to: ekonomický rozvoj, globálne ekonomické partnerstvo a modely konzumu a produkcie, ktoré reprezentujú ekonomický pilier UR. Na túto problematiku sú prierezovo zamerané viaceré povinné predmety, cielene sa danou témou zaoberá napr. povinne volitel'ný predmet Ekonomické aspekty v ekosozológii², ktorý je zameraný na ekonomické aspekty ochrany prírody, hodnotu a oceňovanie služieb ekosystémov, hodnotu druhov a biotopov $v$ širších súvislostiach $s$ ich spoločenskou hodnotou a s oceňovaním ich produkčných a mimoprodukčných funkcií a na zelené účtovníctvo.

Socio-ekonomická téma vládna moc je spojená s inštitucionálnym zabezpečením starostlivosti o životné prostredie a $\mathrm{s}$ inštitucionálnym pilierom $v$ povinnom predmete Starostlivost' o životné prostredie $v$ SR a EÚ 1 a v povinne volitel'nom predmete Organizácia starostlivosti o životné prostredie ${ }^{2}$. Predmet Starostlivost' o životné prostredie v SR a EÚ ${ }^{1}$ poskytuje prehl'ad o súčasnom stave a d'alšom smerovaní starostlivosti o životné prostredie na Slovensku vo väzbe na inštitucionálny poriadok a právny systém v Európskej únii, o 
fungovaní viacúrovňového systému riadenia starostlivosti o životné prostredie (od úrovne EÚ až po miestnu úroveň) a rozdelení právomocí v starostlivosti o životné prostredie na Slovensku medzi orgány štátnej správy a samosprávy (na národnej, regionálnej aj miestnej úrovni), tretí sektor, podnikatel'ský sektor a d’alšie subjekty. Organizácia starostlivosti o životné prostredie ${ }^{2}$ podáva ucelený obraz o štátnej správe v starostlivosti o ŽP, o koncepcii štátnej environmentálnej politiky, oboznamuje s orgánmi štátnej správy a ich právomocami. Venuje sa platnej legislatíve v oblasti ochrany ŽP a súvisiacich zákonov. Rovnako sa zaoberá aj mimovládnymi organizáciami, ktoré sú nezastupitel'nou súčastó $v$ uvedenej sfére. Študenti sa oboznamujú s medzinárodnými projektmi v oblasti ochrany prírody a starostlivosti o ŽP.

Ak porovnáme tematický okruh 2. vládna moc s podtémami korupcia a kriminalita (tab. 2) a zodpovedajúcu tému 2 . dobre spravované verejné veci s podtémami súdržnost' a efektívnost' politiky, otvorenost' a participácia a ekonomické nástroje, uvádzané študijné predmety sú obsahovo zamerané v zmysle chápania podla Eurostat (2011).

Predmety ako Hodnotenie environmentálnych rizík ${ }^{2}$, Prírodné hrozby a riziká v krajine ${ }^{1}$, či Odpady ${ }^{1,2}$ sú zamerané na zdravie, prírodné a antropogénne riziká, zodpovedajú prioritným témam $v$ zmysle Národnej stratégie ochrany biodiverzity SR: Ochrana ovzdušia a boj proti globálnym environmentálnym problémom a Environmentálne vhodné nakladanie s odpadmi. Povinný predmet Hodnotenie environmentálnych rizík ${ }^{2}$ sa zaoberá nebezpečnostou, rizikom, hodnotením a kontrolou rizík. I de o lokálne, regionálne a globálne vplyvy, vnímanie rizík, prírodné katastrofy, hodnotenie humánnych rizík, identifikáciu nebezpečnosti, expozičnú analýzu, vztáah medzi dávkou a odpoved’ou, charakterizovanie rizík. Povinne volitel'ný predmet Prírodné hrozby a riziká v krajine ${ }^{1}$ venuje pozornost' viacerým prírodným procesom, ktoré predstavujú hrozby, napr. hrozbe výmol'ovej erózie, veternej erózie, zamokrenia, zvýšenej akumulácie, gravitačných deformácií, či povodňovej hrozbe, ako aj problematike hodnotenia a identifikácie hrozieb podmienených ludskou činnostou. Povinný predmet Odpady ${ }^{1,2}$ poskytuje prehl'ad o aktuálnej situácii odpadového hospodárstva v SR, o možnostiach zneškodňovania tuhých odpadov spalovaním, skládkovaním, či kompostovaním. Pozornost' sa venuje aj spracovaniu kalov z čistiarní odpadových vôd, biodegradácii ropných uhlovodíkov v zeminách, nakladaniu s rádioaktívnym odpadom, obnovitel'ným zdrojom energie a recyklácii odpadu.

Rozdiel v rámci študijných programov je zrejmý a zodpovedá cielu ich koncipovania. Študijný program 1. Environmentálne plánovanie a manažment je cielene zameraný na problematiku udržatel'ného rozvoja v širokospektrálnom poňatí, študijný program 2 . Ochrana a využívanie prírody a krajiny je užšie orientovaný na prírodné riziká a ochranu biodiverzity. Oba študijné programy poskytujú pomerne široké penzum vedomostí v oblasti udržatel'ného rozvoja, vhodné by bolo však viac motivovat' pedagógov, aby uvedené súvislosti systematicky prezentovali v rámci všetkých predmetov študijných programov.

V súčasnosti na Prírodovedeckej fakulte UK v Bratislave prebieha projekt Medziodborová integrácia pri tvorbe environmentálneho študijného programu $\vee$ anglickom jazyku (2012-2015), ktorého realizácia má podporit' spoluprácu medzi VŠ, organizáciami výskumu a vývoja a súkromným sektorom na národnej a medzinárodnej úrovni. Jeho cielom je vybudovanie dvoch nových bakalárskych študijných programov $v$ anglickom jazyku, ktoré budú vytvorené na základe potrieb pracovného trhu (Abrahámová a kol., 2013). 


\section{Prepojenie teórie s praxou}

Podl'a Katesa a kol. (2005) má najväčší význam definovanie udržatel'ného rozvoja v praxi, čo obsahuje viaceré snahy určit' koncepciu, stanovit́ ciele, vytvorit' indikátory a uplatňovat́ hodnoty. Zároveň zahŕňa sociálne aktivity, podporu vedeckého základu a vyjednávanie kompromisu medzi zástancami prírody a životného prostredia, ekonomického rozvoja a tými, čo sa venujú zlepšeniu podmienok pre človeka.

Podl'a stratégie EHK OSN (2005) pre výchovu k trvalo udržatel'nému rozvoju formálna výchova k UR má byt́ preniknutá životnými a pracovnými skúsenostami mimo školy. Pedagógovia, zapojení do výchovy k UR zohrávajú dôležitú úlohu v napomáhaní tohto procesu a podporovaní dialógu medzi žiakmi, študentmi, inštitúciami a občianskou spoločnostou. Takéto zameranie umožňuje systému vzdelávania prekonat' jeho izoláciu od spoločnosti.

Environmentálne vzdelávanie naliehavo volá po rozšírení a prehíbení priameho kontaktu študentov s terénom. Snaha o maximálne využívanie bezprostredného kontaktu s prírodou, práce so živými prírodninami a priame pozorovanie na biotopoch by sa mali stat' výraznou dominantou environmentálneho vzdelávania (Nevřelová, 2008). Zručnosti a návyky získavané pri terénnych exkurziách a cvičeniach realizovaných priamo v teréne sú jednou z hlavných podmienok pre potreby praxe v ochrane prírody. Z hladiska rozvoja kompetencií študentov $v$ oblasti aplikácie získaných poznatkov v praxi má mimoriadny význam výučba formou terénnych práce a exkurzií. V magisterskom stupni štúdia terénne práce plynule nadväzujú na terénne práce bakalárskeho štúdia. Terénne práce z manažmentu krajiny sú zamerané predovšetkým na priame mapovanie významných segmentov krajiny v teréne vo vybranom regióne Slovenska. Ich súčastóou je aj zapojenie študentov do praktických manažmentových zásahov v rôznych typoch ekosystémov. Terénny výskum vo vybranom chránenom území a vzdelávacie exkurzie zamerané na manažment vybraných biotopov a rastlinných a živočišnych taxónov tvoria výrazný podiel aj v predmete Regionálna ekosozológia Slovenska, ktorý je poznatkami orientovaný na regióny, územia Slovenska s hodnotením ekologickej kvality, biodiverzity, genofondu a ekosozologicky významných prvkov priestorovej štruktúry krajiny. V rámci predmetu Praktický manažment bioty sa študenti podiel'ajú na priamej realizácii manažmentových opatrení vybraných druhov a biotopov v spolupráci $\mathrm{S}$ pracovníkmi Štátnej ochrany prírody SR a mimovládnych organizácií.

Terénne exkurzie sú v priebehu celého štúdia orientované na poznanie a ochranu druhov a biotopov vo vzt́ahu k funkciám a spôsobom využívania súčasnej krajiny. Okrem povinných terénnych prác majú študenti možnost' zúčastňovat́ sa aj doplnkových, tematicky zameraných terénnych exkurzií. Ciel'om pravidelných exkurzií sú vybudované migračné objekty pre zver v Rakúsku a Mad’arsku. Dlhodobú tradíciu majú exkurzie na lokality dávnejšie aj novo založených biocentier a biokoridorov na Slovensku a v Českej republike. Zaujímavou destináciou s podnetnými informáciami sú národné parky v susedných krajinách (NP Donau Auen a NP Neusiedlersee - Seewinkel). Pravidelne je velký záujem o exkurziu na Velkolélsky ostrov pri Komárne, kde sú realizované revitalizačné projekty, zamerané na ochranu biodiverzity ekosystému Dunaja v súlade s obnovou, udržatel'ného, tradičného využívania lúk a pasienkov. Organizované terénne exkurzie predstavujú jednu z aktívnych foriem vzdelávania k udržatel'nému rozvoju.

\section{Diplomové práce - výstupy v rámci vedecko-výskumných grantov}

Študenti sa v rámci diplomových prác venujú získavaniu údajov v teréne, interpretácii a vyhodnocovaniu výsledkov výskumu. Témy prác sú orientované najmä na získavanie skúseností v ochrane prírody a udržatel'nom rozvoji, zamerané sú na ochranu a manažment 
vybraných druhov rastlín a živočíchov, prípadne na hodnotenie krajinných prvkov a ekologickú kvalitu krajiny. Ciel'om je zapájat' študentov do grantových projektov, ktoré na pracoviskách prebiehajú.

V súčasnosti už mnohí absolventi uvedeného štúdia pôsobia v environmentálnej praxi v štátnych inštitúciách s pôsobnostó ochrany prírody (Štátna ochrana prírody SR, Slovenská agentúra životného prostredia, Ministerstvo životného prostredia, odbory starostlivosti o životné prostredie na okresných úradoch), alebo $\mathrm{v}$ mimovládnych organizáciách (napr. DAPHNE - Inštitút aplikovanej ekológie, Bratislavské regionálne ochranárske združenie BROZ, Slovenská ornitologická spoločnost'/BirdLife Slovensko) a takto prispievajú k rozvoju ekologického a environmentálneho povedomia a realizujú svoje vedomosti priamo $v$ praxi ochrany prírody.

\section{Diskusia a záver}

Metodický postup analýzy študijných programov magisterského štúdia Environmentálne plánovanie a manažment a Ochrana a využívanie prírody a krajiny bol zameraný na vyhodnotenie obsahu prednášok, seminárov a cvičení povinných a povinne volitel'ných predmetov. Pozornost' bola sústredená na prezenciu, resp. absenciu tematických okruhov udržatel'ného rozvoja (UR) $v$ jednotlivých predmetoch $v$ rámci výučby. Následne bolo vyhodnotené 1) percento predmetov, ktoré obsahujú daný tematický okruh a 2) zastúpenie tematických okruhov $v$ rámci jednotlivých predmetov. Študijné programy a štruktúra obsahového zamerania boli hodnotené na základe 14 tematických okruhov Komisie OSN ( 1. chudoba, 2. vládna moc, 3. zdravie, 4. vzdelanie, 5. demografia, 6. prírodné riziká, 7. atmosféra, 8. krajina, 9. oceány, moria a pobrežia, 10. sladká voda, 11. biodiverzita, 12. ekonomický rozvoj, 13. globálne ekonomické partnerstvo, 14. modely konzumu a produkcie), nakolko prehl'adne prezentujú nosné témy udržatel'ného rozvoja. Z hl'adiska porovnania po úroveň podtém sú tematické okruhy v zmysle OSN (United Nations, 2007) a podla Európskej únie (Eurostat, 2011) chápané vel'mi podobne.

Z analýzy študijných programov z hladiska pokrytia 14 tematických okruhov udržatel'ného rozvoja vyplynulo, že nosnými témami v rámci obidvoch hodnotených študijných programov sú prírodné riziká, krajina a biodiverzita, čo zodpovedá environmentálnemu pilieru udržatel'ného rozvoja. Štúdium však poskytuje vedomosti aj v rámci d’alších pilierov, viaceré predmety pokrývajú ekonomický a inštitucionálny pilier, okrajovo je zastúpený sociálny pilier.

Výsledky analýz ukázali, že 20 predmetov z celkového počtu 41 pokrýva 7-14 (viac ako $50 \%$ ) tematických okruhov UR. V študijnom programe Environmentálne plánovanie a manažment je to 7 povinných a 4 povinne volitel'né predmety. Všetky tematické okruhy UR pokrýva predmet Udržatel'ný rozvoj - od teórie k praxi. Uvedený študijný program bol od začiatku koncipovaný s dôrazom na získanie kompetencií absolventov v oblasti udržatel'ného rozvoja, čomu zodpovedá aj široké spektrum interdisciplinárnych predmetov, ktoré poskytujú znalosti aj získavanie praktických zručností pre prax. $V$ študijnom programe Ochrana a využívanie prírody a krajiny pokrývajú viac ako 7 tematických okruhov UR 4 povinné a 3 povinne volitel'né predmety. Študijný program je viac orientovaný na problematiku ochrany prírody, biodiverzity a environmentálnej ekológie, čomu zodpovedá štruktúra a obsahové zameranie predmetov. $V$ súvislosti s novou akreditáciou je pripravované posilnenie študijného programu $v$ oblasti environmentálnej ekológie. Dva predmety sú spoločné pre oba študijné programy. Obsahovo sú hodnotené študijné programy postavené v súlade so stanovenými profilmi absolventov a s obsahovým zameraním štúdia na Prírodovedeckej fakulte 
UK v Bratislave a majú potenciál poskytnút absolventom dostatočné kompetencie pri uplatňovaní princípov udržatel'ného rozvoja v praxi od štátnej správy, cez mimovládne organizácie až po oblast' vedy a výskumu. Záleží však aj od d'alšej praxe absolventov a od ich celoživotného vzdelávania. Podl'a Blaška (2010) majú klúčové kompetencie dlhšiu životnost́ ako odborná kvalifikácia, nadobúdanie klúčových kompetencií je celoživotný proces, udržovaný dynamikou nového vzdelávania a rekvalifikácie človeka.

Z Akčného plánu výchovy a vzdelávania $k$ trvalo udržatel'nému rozvoju $v$ SR na roky 2006- 2010 vyplývajú viaceré úlohy, ktoré podporujú udržatel'ný rozvoj SR. V tejto súvislosti sa zdôrazňuje aj významné postavenie vysokých škôl v kontexte dosahovania cielov udržatel'ného rozvoja. Komplexný význam vysokých škôl vo vzt́ahu k UR zdôraznili Sedlačko, Kozová (2007). Podla autorov vysoké školy ako organizácie sú aj spotrebitel'mi a zamestnávatel'mi - preto trvalo udržatel'né vysoké školy rozvíjajú schopnosti trvalo udržatel'nej prevádzky a riadenia (ktoré sa týkajú spotreby energie a materiálov, tvorby a nakladania s odpadmi, dopravy, stravovania, obstarávania výrobkov a služieb, personálnej politiky).

Širokospektrálne chápanie udržatel'ného rozvoja nachádza odozvu vo vysokoškolskom štúdiu na rôzne zameraných vysokých školách. Rozdielny obsah štúdia so zameraním na udržatel'ný rozvoj a iné ciele prípravy absolventov je zrejmý napr. pri porovnaní viacerých študijných programov $v$ rámci vysokých škôl SR. Vzdelávanie $k$ udržatel'nému rozvoju v rámci prípravy študentov učitel'ských aprobácií na Prírodovedeckej fakulte UK v Bratislave analyzovala Chrenščová (2008). Podla uvedenej autorky je úroveň environmentálneho vzdelávania budúcich učitelov rôzna, a to ako z hladiska rozsahu, tak aj obsahu výučby. Environmentálne vzdelávanie budúcich učitelov sa líši v rámci rôznych študijných odborov a jednotlivých aprobácií.

Na Fakulte manažmentu Prešovskej univerzity bol v roku 2011 akreditovaný študijný program Environmentálny manažment. Výučba $v$ tomto študijnom programe sa začala od akademického roka 2012/2013. Jeho absolventi by mali byt' schopní prijímat́ efektívne manažérske rozhodnutia vo väzbe na trvalo udržatel'ný rozvoj, alebo tiež majú dokázat' pracovat́ so všetkými vekovými skupinami obyvatel'stva s cielom formovat' ich environmentálne uvedomenie. Ambíciou programu nie je vychovávat' rigorózneho environmentalistu, produktom vzdelávania $v$ danom programe by mal byt́ absolvent, ktorý má ( $v$ bakalárskom stupni štúdia) široký prírodovedný základ bazálnych disciplín chémie, ekológie, environmentalistiky, na ktoré potom nadväzujú profilujúce predmety prierezových disciplín environmentálneho manažmentu ako prieniku prírodovedného a spoločenskovedného pohladu na danú oblast́ (Adamišin, Chovancová, 2013).

Užšie špecializovaný obsah štúdia v porovnaní s Prírodovedeckou fakultou UK v Bratislave $v$ oblasti udržatel'ného rozvoja poskytuje Slovenská pol'nohospodárska univerzita v Nitre. Katedra udržatel'ného pol'nohospodárstva a herbológie na Fakulte agrobiológie a potravinových zdrojov zabezpečuje výučbu predmetov, zameraných na oblasti udržatel'ného a ekologického pol'nohospodárstva, agroenvironmentálnych indikátorov udržatel'nosti, projektovania udržatel'ných pol'nohospodárskych systémov a rozvoj mimoprodukčných funkcií polnohospodárstva a agroturistiky. Ide o témy, vyučované $v$ rámci predmetov inžinierskeho stupňa štúdia: Projektovanie udržatel'ných pol'nohospodárskych systémov a Udržatel'né a ekologické pol'nohospodárstvo (www.fapz.uniag.sk). Na Fakulte európskych štúdií a regionálneho rozvoja SPU Nitra zabezpečujú študijný program - Environmentálne manažérstvo $\checkmark$ prvom i druhom stupni, $v$ dennej i externej forme štúdia dve katedry - Katedra ekológie a Katedra udržatel'ného rozvoja (Eliáš, 2013).

Otázka „výstupných“ znalostí absolventov podla Neubergovej (2009) úzko súvisí s požiadavkami praxe. V ideálnom prípade by sa študenti mali zasadzovat' o aplikáciu myšlienky 
trvalej udržatel'nosti v praxi a jej využitie v praxi by malo spätne vysielat' svoje požiadavky, na ktoré by zasa vysokoškolské vzdelanie malo pružne reagovat'.

Ak hodnotíme absolventov prezentovaných študijných programov na Prírodovedeckej fakulte UK v Bratislave podla spätnej väzby, ich uplatnenie $v$ praxi je pozitívne $v$ tom, že nachádzajú priestor pôsobenia a uplatňujú princípy udržatel'ného rozvoja $\vee$ praxi $\vee$ štátnych inštitúciách s pôsobnostou ochrany prírody, alebo $v$ mimovládnych organizáciách, aj $v$ takých, ktoré priamo založili. Napr. mimovládna organizácia BROZ si vd’aka podpore programu Európskej komisie LIFE-Nature prenajala na 25 rokov 250 ha pozemkov na Velkolélskom ostrove, kde realizuje projekt ochrany lesov, obnovy zanedbaných lúk, znovu zavedenia pasenia hospodárskych zvierat a spolupráce s miestnou komunitou.

\section{Pod’akovanie}

Príspevok vznikol s podporou projektu ERDF: SPECTRA+ No. 20240120002 “Centre of Excellence for the Development of Settlement Infrastructure of Knowledge Economy".

\section{Literatúra}

- Abrahámová, A., Pavličková, K., Fedor P., 2013: Medziodborová integrácia pri tvorbe environmentálneho študijného programu v anglickom jazyku. Zborník vybraných príspevkov z konferencie Stav a perspektívy environmentálneho vzdelávania, Univerzita Komenského v Bratislave, Prírodovedecká fakulta, s. 119-127.

- Adamišin, P., Chovancová. J., 2013: Environmentálne vzdelávanie na Prešovskej univerzite v Prešove ako nová výzva vo vzt́ahu k realizovanému Univerzitnému vedeckému parku TECHNICOM. Zborník vybraných príspevkov z konferencie Stav a perspektívy environmentálneho vzdelávania, Univerzita Komenského v Bratislave, Prírodovedecká fakulta, s. 16-27.

- Blaško, M., 2010: Rozvíjanie klúčových kompetencií vo vzdelávaní. Technická univerzita v Košiciach. [online]. [cit. 2014-12-28]. Dostupné na: http://web.tuke.sk/kip/download/vuc42.pdf

- CČ́k, G., 2013: Perspektívy rozvoja štúdia environmentálneho inžinierstva na Slovenskej technickej univerzite v Bratislave. Zborník vybraných príspevkov z konferencie Stav a perspektívy environmentálneho vzdelávania, Univerzita Komenského v Bratislave, Prírodovedecká fakulta, s. 28-36.

- $\quad$ EHK, 2005: Stratégia EHK OSN pre výchovu k trvalo udržatel'nému rozvoju. Európska hospodárska komisia, Výbor pre environmentálnu politiku. $15 \mathrm{~s}$. [online]. [cit. 2014-11-15]. Dostupné na: http://www.unece.org/fileadmin/DAM/env/esd/strategytext/Slovak.pdf

- Eliáš, P., 2013: Stav výučby ekológie a environmentalistiky na Slovenskej pol'nohospodárskej univerzite v Nitre. Zborník vybraných príspevkov z konferencie Stav a perspektívy environmentálneho vzdelávania, Univerzita Komenského v Bratislave, Prírodovedecká fakulta, s. 37-45.

- $\quad$ Eurostat, 2011: Sustainable development in the European Union. 2011 monitoring report of the EU sustainable development strategy. 382 s. [online]. [cit. 2014-1115]. Dostupné na: http://www.ecologic.eu/4581 
- Fedor, P., 2013: Predhovor. Zborník vybraných príspevkov z konferencie Stav a perspektívy environmentálneho vzdelávania, Univerzita Komenského v Bratislave, Prírodovedecká fakulta, s. 6.

- Fedor, P., Pavličková, K. (eds.) 2013: Zborník vybraných príspevkov z konferencie Stav a perspektívy environmentálneho vzdelávania, Univerzita Komenského v Bratislave, Prírodovedecká fakulta, 247 s. [online]. [cit. 2014-12-15]. Dostupné na: http://www. krajinnaekologia.sk/subory/zbornik-prispevkov.pdf

- Füry, D., Hlatká, M., 2013: Obraz človeka súčasnosti a budúcnosti vo vedomí vysokoškolských študentov. Zborník vybraných príspevkov z konferencie Stav a perspektívy environmentálneho vzdelávania, Univerzita Komenského v Bratislave, Prírodovedecká fakulta, s. 53-64.

- Gallayová, Z., 2013: Zhodnotenie výučby Environmentálnej výchovy a súvisiacich aktivít na Fakulte ekológie a environmentalistiky v období 1997-2013. Zborník vybraných príspevkov z konferencie Stav a perspektívy environmentálneho vzdelávania, Univerzita Komenského v Bratislave, Prírodovedecká fakulta, s. 65-77.

- Hilbert, H., 2007: Súčasný stav a perspektívy vzdelania v oblasti TUR na Slovensku. Ekológia a environmentalistika, Zvolen, 2007, s. 36-48.

- Huba, M., 2013: Interpelácia ministra školstva - vec: environmentálna výchova a vzdelávanie. [online]. [cit. 2014-11-15]. Dostupné na: http://www.czp.cuni.cz/envigogika/ index.php/cz/inspirace/2013/envigogika-2013-viii-1/784-interpelacia-ministra-skolstva-vec-environmentalna-vychova-a-vzdelavanie?highlight $=$ WyJ $0 \mathrm{dXI}$ iXQ==

- Chrenščová, V., 2008: Výchova a vzdelávanie k udržatel'nému rozvoju v rámci prípravy študentov učitel'ských aprobácií na Prírodovedeckej fakulte UK v Bratislave. Zborník príspevkov zo seminára „Výchova a vzdelávanie $\mathrm{k}$ TUR na slovenských vysokých školách“, 20. 11. 2008, s. 5-8.

- Kates, R. W., Parris, T. M., Leiserowitz, A. A., 2005: What Is Sustainable Development? Goals, Indicators, Values, and Practice. Environment: Science and Policy for Sustainable Development, 47(3), s. 8-21 [online]. [cit. 2014-12-15]. Dostupné na: http://www. heldref.org/env. php

- Kminiak, M., 1997: Environmentálna výchova. Prírodovedecká fakulta, Univerzita Komenského, Bratislava, AP, Patocs Attila, $97 \mathrm{~s}$.

- Kocian, L'., 2013: Mikuláš Lisický - zakladatel' ekosozológie. Zborník vybraných príspevkov z konferencie Stav a perspektívy environmentálneho vzdelávania, Univerzita Komenského v Bratislave, Prírodovedecká fakulta, s. 8-15.

- Koločány, F., 2006: Akčný plán trvalo udržatel'ného rozvoja Slovenska 2005-2010. Enviromagazín, 2/2006, s. 4-5.

- Kozová, M., 2007: Výchova a vzdelávanie k TUR na slovenských vysokých školách, Enviromagazín 2/2007, s. 14 [online]. [cit. 2014-11-15]. Dostupné na: http://www. enviromagazin.sk/enviro2007/enviromc2/09.pdf

- Kozová, M., 2008: Príklady predmetov podporujúcich výchovu k udržatel'nému rozvoju v interdisciplinárne orientovaných študijných programov na Prírodovedeckej 
fakulte UK v Bratislave. Zborník príspevkov zo seminára „Výchova a vzdelávanie $\mathrm{k}$ TUR na slovenských vysokých školách“, 20. 11. 2008, s. 13-16.

- Nevřelová, M., 2008: Environmentálna výučba vo výchovno-vzdelávacom procese. CICERO s.r.o., Bratislava, 90 s.

- Nevřelová, M., 2013: Ekosozológia. Univerzita Komenského v Bratislave, Bratislava, $80 \mathrm{~s}$.

- Neubergová, K., 2009: Hledání možných cest k uchopení výuky trvale udržitelného rozvoje na technických vysokých školách. Envigogika 2009/IV/2 [online]. [cit. 2014-11-28]. Dostupné na: http://www.envigogika.cuni.cz/index.php/Envigogika/article/view/138/146

- Pauditšová, E., 2012: Dvadsat'ročná história Katedry krajinnej ekológie Prírodovedeckej fakulty Univerzity Komenského v Bratislave. Acta Environmentalica Universitatis Comenianae (Bratislava), 20(2), s. 103-108.

- Rybárová, B., 2014a: Študijná ročenka v akademickom roku 2014/2015. Bakalársky stupeň štúdia. Univerzita Komenského v Bratislave, Prírodovedecká fakulta, Bratislava, $104 \mathrm{~s}$.

- Rybárová, B., 2014b: Študijná ročenka v akademickom roku 2014/2015. Magisterský stupeň štúdia. Univerzita Komenského v Bratislave, Prírodovedecká fakulta, Bratislava, $94 \mathrm{~s}$.

- Sedlačko, M., Kozová, M., 2007: Vysoké školstvo je v procese prechodu spoločnosti k trvalej udržatel'nosti klúčovým hráčom. Enviromagazín 2/2007, s. 16 [online]. [cit. 2014-11-15]. Dostupné na: http://www.enviromagazin.sk/enviro2007/enviromc2/09.pdf

- United Nations, 2007: Indicators of Sustainable Development: Guidelines and Methodologies Third Edition, New York, USA, 93 s. [online]. [cit. 2014-11-15]. Dostupné na: http://www.un.org/esa/sustdev/natlinfo/indicators/ guidelines. pdf

- http://www.fapz.uniag.sk/

- http://www.fns.uniba.sk/

- http://www. portalvs.sk/sk/studijne-odbory/ 